\section{Health care seeking behavior and patient delay in tuberculosis diagnosis}

\author{
Comportamento de busca por cuidados em \\ saúde e atraso do paciente no diagnóstico \\ da tuberculose
}

\author{
Comportamiento de búsqueda de atención de \\ salud y retraso del paciente en el diagnóstico \\ de la tuberculosis
}

\begin{abstract}
1 Faculdade de Medicina, Universidade Federal do Rio Grande do Sul, Porto Alegre, Brasil.

Correspondence

D. R. Silva

Programa de Pós-Graduação em Ciências Pneumológicas da Faculdade de Medicina da Universidade Federal do Rio Grande do Sul.

Rua Ramiro Barcelos 2350, Porto Alegre, RS 90035-903, Brasil.

denise.rossato@terra.com.br
\end{abstract}

\begin{abstract}
Delays in diagnosis of TB cases are major impeding factors in the control of TB. The objectives of this study were to describe the health care seeking behavior of TB patients, assessing patient delay and the number of health care facilities visited before the start of TB treatment. A crosssectional study was carried out with adult patients with pulmonary TB presenting to two TB facilities to start treatment. We found a median patient delay of 20 days. The factors associated negatively with patient delay in multivariate analysis were weight loss, and have sought treatment because of the first symptom. We also demonstrated that $44.8 \%$ of patients incorrectly reported the mode of transmission of TB. In addition, the local of first attendance was an emergency room of public hospitals in 37.3\% of patients. We demonstrated that the median patient delay in TB diagnosis in two TB services in a region with a high prevalence of TB was 20 days, and the protective factors associated with this delay in multivariate analysis were weight loss, and have sought treatment because of the first symptom.
\end{abstract}

Tuberculosis; Delayed Diagnosis;

Time-to-Treatment
Carlos Podalirio Borges de Almeida 1 Erika Cavalheiro Skupien 1

Denise Rossato Silva ${ }^{1}$

\section{Resumo}

Atrasos no diagnóstico de casos de tuberculose são os principais fatores que impedem o controle da doença. Os objetivos deste estudo foram descrever a trajetória de pacientes com tuberculose, avaliando a demora do paciente e o número de unidades de saúde visitadas antes do início do tratamento. Estudo transversal foi conduzido com pacientes com idade $\geq 18$ anos e com diagnóstico de tuberculose pulmonar, que responderam a um questionário. A média de idade dos pacientes foi de 40,4 $\pm 16,1$. Foi encontrada uma mediana de 20 dias no atraso dos pacientes. Também foi verificado que 44,8\% relataram incorretamente o modo de transmissão da tuberculose. Além disso, o local do primeiro atendimento para 37,3\% dos pacientes foi uma emergência de hospital público. Encontrou-se uma mediana de 20 dias no atraso dos pacientes até o diagnóstico da tuberculose; os fatores protetores associados a este atraso na análise multivariada foram perda de peso e ter procurado tratamento por causa do primeiro sintoma.

Tuberculose; Diagnóstico Tardio; Tempo para o Tratamento 


\section{Introduction}

Tuberculosis (TB) is a major public health issue worldwide, particularly in low- and middle-income countries 1 . Delays in diagnosis and treatment of TB cases are major impeding factors in the control of TB. A single infectious person who remains untreated can infect between ten and fifteen people every year, spreading the infection in the community 1,2 . In addition, delayed TB diagnosis and treatment may result in more extensive disease and more complications, and increases the risk of mortality $3,4,5$.

The total delay in TB diagnosis can be divided into the length of patient delay and the length of health care system delay 6 . Socio-economic status, perceived severity of illness and symptom recognition, distance and physical access, and perceived quality and cost of health service provision are all factors associated with patient delay 7 .

Previous studies have shown that a delay in diagnosis is closely related to poor access to health care 8,9 . Despite TB control programs' recommendation that diagnosis should be made at the primary health care level, most patients are still diagnosed in hospitals. In fact, in Porto Alegre, Rio Grande do Sul State, Southern Brazil, 38.98\% of TB cases were reported by hospitals 10 . Understanding the factors related to delay in diagnosis of disease is essential to reduce the period of transmission and the risk of exposure of other community members.

The objectives of this study were to describe the health care seeking behavior of TB patients, assessing patient delay and the number of health care facilities visited before the start of TB treatment.

\section{Materials and methods}

We conducted a cross-sectional study in two TB services, located in the city of Porto Alegre, between February and December 2012. Porto Alegre is the city with the highest incidence of TB in Brazil (115 cases/100,000 population), with a cure rate of $67 \%$. Also, the TB-HIV co-infection rate is the highest in the country (35\%) 11.

All adult patients ( $\geq 18$ years old) with pulmonary TB presenting to the two facilities that admit TB patients to start treatment were invited to participate. Pulmonary TB was diagnosed according to any of the following criteria established in the Brazilian Guidelines for Tuberculosis ${ }^{12}$. Patients who refused signing the consent form were excluded from the study.

Face-to-face interviews were performed using a standardized and pre-tested questionnaire developed exclusively for this study to collect information on each patient at the time of admission. The interviews were conducted by the same interviewer, previously trained. Medical records were also reviewed. The following data were recorded: demographic data, symptoms before seeking health care, health care seeking behavior, type and number of health care facilities visited, and knowledge about TB.

Health care seeking time was defined as the duration (in days) between the onset of symptoms to the first visit to a health care facility (including hospital, TB services, primary health care clinics, etc). In order to evaluate the associated factors with patient delay, the study population was divided into two groups, according to the median time of health care seeking: group 1 ( $\geq$ median) and group $2(<$ median). Individuals included in group 1 were considered to have "patient delay".

Data analysis was performed using SPSS 18.0 (IBM Corp., Armonk, United States). Data were presented as number of cases, mean \pm standard deviation (SD), or median with interquartile range (IQR). Categorical comparisons were performed by chi-square test using Yates's correction if indicated or by Fisher's exact test. Continuous variables were compared using the $t$-test or Wilcoxon test. Multivariate logistic regression analysis was used to evaluate risk factors for patient delay, using selection of factors associated ( $\mathrm{p} \leq$ 0.20 ) with delay in univariate analysis or those known to have clinical significance. Stepwise regression models were also examined to evaluate the possible collinearity among the predictors. The predictors selected in the final model were based on both statistical and clinical sig nificance. The goodness of fit of the multiple logistic regression models was assessed using the Hosmer-Lemeshow test. Odds ratios (ORs) and nominal 95\% confidence intervals (95\%CIs) were presented. A two-sided p-value $<0.05$ was considered significant for all analyses.

On the basis of data from van derWerf et al. 13, who informed that individuals reporting unemployment, cough or loss of weight before seeking health care had a longer patient delay, we estimated a sample size of 134 patients, under the assumptions of a type I error (two-sided) of $5 \%$ and a type II error of $10 \%$.

\section{Results}

One hundred thirty-nine patients met the inclusion criteria. Five patients refused to participate, then one hundred thirty-four patients were included in the analysis. The mean age of all pa- 
tients was $40.4 \pm 16.1$ years, $62.7 \%$ were males, and $59 \%$ were white. The majority of patients were literate and unemployed. Twenty-three patients $(17.1 \%)$ were HIV positive. The characteristics of participants are summarized in Table 1.

Health seeking behavior, knowledge and perspectives of TB patients were described in Table 2. One hundred and seven patients (79.9\%) sought treatment after the first symptom of TB. Among those who did not seek treatment soon after the onset of the first symptom, $44.8 \%$ did not because they thought the symptom was normal, $21.6 \%$ thought would improve without treatment, and $7.5 \%$ said that they could not miss work to sought treatment. One hundred and two patients $(76.1 \%)$ sought care elsewhere before TB health center. The type of facility first sought by patients was: emergency of a public health hospital $(\mathrm{n}=50,49.1 \%)$, public health center $(\mathrm{n}=$ $35,34.3 \%)$, private practice $(n=11,10.8 \%)$, and emergency of a private hospital ( $\mathrm{n}=6,5.9 \%$ ). Overall, the median number of visits to health care facilities before the diagnosis was 3 (IQR: $2-4)$. Thirty seven patients $(27.6 \%)$ were diagnosed and started treatment at hospitals, and did not seek treatment at health centers. The reasons for not seeking treatment in health centers were: "it is difficult to get medical care there" $(n=15)$, "I thought my problem would not be solved there" ( $\mathrm{n}=12$ ), "I don't know where is the health center I should go" ( $\mathrm{n}=7$ ), and "I did not know I could seek a health center for this problem” $(n=3)$.

The median health care seeking time was 20 days (IQR: 7-46.3 days). According to this median time, 71 (52.9\%) patients were included in group 1 ( $\geq 20$ days), and 63 (47\%) in group 2 ( $<20$ days). Table 3 summarizes the results of the univariate analysis. By univariate analysis, characteristics associated negatively with delayed initial health seeking were weight loss, sought care after the first symptom, and smear positive sputum.

Logistic regression analysis estimating the ORs of risk of patient delay was conducted. Age, sex, monthly household income $<1$ stan-

Table 1

Characteristics of study population $(n=134)$.

\begin{tabular}{lc}
\hline Characteristics & $\mathbf{n}(\%)$, mean \pm SD or median (IOR) \\
\hline Age (years) & $40.4 \pm 16.1$ \\
Male sex & $84(62.7)$ \\
White race & $79(59.0)$ \\
Marital status & \\
$\quad$ Single & $76(56.7)$ \\
$\quad$ Married & $39(29.1)$ \\
$\quad$ Divorced/Separeted & $10(7.5)$ \\
$\quad$ Widowed & $9(6.7)$ \\
$<8$ years of schooling & $60(44.8)$ \\
Literate & $127(94.8)$ \\
Employed & $60(44.8)$ \\
Living alone & $26(19.4)$ \\
Has a religion & $99(73.9)$ \\
Monthly household income $<1$ standard minimum wage * & $35(26.1)$ \\
Institutionalization & $39(29.1)$ \\
Smoking habit & \\
$\quad$ Never smokers & $41(30.6)$ \\
Current smokers & $45(33.6)$ \\
Former smokers & $48(35.8)$ \\
Alcoholism & $13(9.7)$ \\
Drug use & $14(10.4)$ \\
HIV positive & $23(17.1)$ \\
\hline F interguatle ran &
\end{tabular}

IQR: interquartile range; SD: standard deviation.

* 1 standard minimum wage corresponds to approximately US\$ 311. 
Health seeking behavior, knowledge and perspectives of TB patients $(n=134)$.

\begin{tabular}{|c|c|}
\hline & $\begin{array}{l}\mathrm{n}(\%), \text { mean } \pm \mathrm{SD} \text { or } \\
\text { median (IOR) }\end{array}$ \\
\hline Feels sick & $96(71.6)$ \\
\hline \multicolumn{2}{|l|}{ Symptoms of disease } \\
\hline Cough & $57(65.5)$ \\
\hline Fever & $59(53.6)$ \\
\hline Fatigue & $18(13.4)$ \\
\hline Night sweats & $73(69.5)$ \\
\hline Dyspnea & $61(54.0)$ \\
\hline Weight loss & $89(80.2)$ \\
\hline Sought treatment because of first symptom & 107 (79.9) \\
\hline Time to first health seeking, days & $20.0(7.0-46.3)$ \\
\hline \multicolumn{2}{|l|}{ Why not sought treatment before? } \\
\hline Thought the symptoms were normal & $60(44.8)$ \\
\hline Thought would improve without treatment & $29(21.6)$ \\
\hline Could not miss work to sought treatment & $10(7.5)$ \\
\hline Someone suggested that you seek care & $89(66.4)$ \\
\hline Sought care elsewhere before TB health center & $102(76.1)$ \\
\hline \multicolumn{2}{|l|}{ Where? } \\
\hline Public health center & $35(26.1)$ \\
\hline Emergency of a public hospital & $50(37.3)$ \\
\hline Emergency of a private hospital & $6(4.5)$ \\
\hline Private practice & $11(8.2)$ \\
\hline Number of facilities sought before diagnosis & $3(2-4)$ \\
\hline Chest $\mathrm{x}$-ray was requested somewhere & $77(57.5)$ \\
\hline Sputum smear was requested somewhere & $49(36.6)$ \\
\hline Medication was prescribed somewhere & $49(36.6)$ \\
\hline Previous TB & $35(26.1)$ \\
\hline Smear positive sputum & $102(76.1)$ \\
\hline Correctly reported air as the main mode of transmission of TB & $74(55.2)$ \\
\hline Perceived TB as being curable & $128(95.5)$ \\
\hline Afraid of how other people will react when they know you have TB & $52(38.8)$ \\
\hline $\begin{array}{l}\text { Afraid that your friends and/or family members to move away from you if they know } \\
\text { you have TB }\end{array}$ & $31(23.1)$ \\
\hline Feel alone after discovering that you have TB & $27(20.1)$ \\
\hline Concerned to keep away from others to avoid spreading TB & $92(68.7)$ \\
\hline $\begin{array}{l}\text { Afraid or ashamed to appear in the TB health center because other people can see } \\
\text { that you are going there because you have TB }\end{array}$ & $11(8.2)$ \\
\hline Feels guilty for your family to have to be taking care of you & $24(17.9)$ \\
\hline $\begin{array}{l}\text { Afraid to tell others that you have TB because they may find that you also have HIV/ } \\
\text { AIDS }\end{array}$ & $38(28.4)$ \\
\hline Fear of having HIV/AIDS & $71(53.0)$ \\
\hline $\begin{array}{l}\text { Feels guilty for having TB due to some of your habits (smoking or use of alcohol } \\
\text { beverages or other drug use) }\end{array}$ & $54(40.3)$ \\
\hline
\end{tabular}

IQR: interquartile range; SD: standard deviation.

dard minimum wage, weight loss, night sweats, fever, sought treatment after the first symptom, and previous TB were included in the multivari- ate analysis. The variables associated with patient delay in multivariate logistic regression are shown in Table 4. 
Table 3

Univariate analysis of factors associated with patient delay.

\begin{tabular}{|c|c|c|c|}
\hline & $\begin{array}{c}\text { Group } 2 \\
\text { Patient delay }<20 \text { days } \\
(n=63)\end{array}$ & $\begin{array}{c}\text { Group } 1 \\
\text { Patient delay } \geq 20 \text { days } \\
(n=71)\end{array}$ & p-value \\
\hline Age (years) & $38.1 \pm 14.1$ & $42.4 \pm 17.5$ & 0.125 \\
\hline Male sex & $39(61.9)$ & $45(63.4)$ & 0.999 \\
\hline White race & $36(57.1)$ & $43(60.6)$ & 0.727 \\
\hline$<8$ years of schooling & $26(41.3)$ & $34(47.9)$ & 0.489 \\
\hline Literate & $60(95.2)$ & $67(94.4)$ & 0.999 \\
\hline Employed & $30(49.2)$ & $29(40.8)$ & 0.595 \\
\hline Living alone & $11(17.5)$ & $15(21.1)$ & 0.665 \\
\hline Has a religion & $44(69.8)$ & $55(77.5)$ & 0.332 \\
\hline Monthly household income $<1$ standard minimum wage * & $20(31.7)$ & $15(21.1)$ & 0.174 \\
\hline Institutionalization & $20(31.7)$ & $19(26.8)$ & 0.571 \\
\hline \multicolumn{4}{|l|}{ Smoking habit } \\
\hline Never smokers & $19(30.2)$ & $22(31.0)$ & 0.999 \\
\hline Current smokers & $20(31.7)$ & $25(35.2)$ & 0.716 \\
\hline Former smokers & $24(38.1)$ & $24(33.8)$ & 0.718 \\
\hline Alcoholism & $7(11.1)$ & $6(8.5)$ & 0.771 \\
\hline Drug use & $7(11.1)$ & $7(9.9)$ & 0.999 \\
\hline HIV positive & $13(24.1)$ & $10(16.9)$ & 0.362 \\
\hline Feels sick & $44(69.8)$ & $52(73.2)$ & 0.704 \\
\hline \multicolumn{4}{|l|}{ Symptoms of disease } \\
\hline Cough & $31(72.1)$ & $26(59.1)$ & 0.261 \\
\hline Fever & $31(60.8)$ & $28(47.5)$ & 0.183 \\
\hline Fatigue & $8(12.7)$ & $10(14.1)$ & 0.999 \\
\hline Night sweats & $39(78.0)$ & $34(61.8)$ & 0.091 \\
\hline Dyspnea & $29(54.7)$ & $32(53.3)$ & 0.999 \\
\hline Weight loss & $47(88.7)$ & $42(72.4)$ & 0.035 \\
\hline Sought treatment because of first symptom & $57(90.5)$ & $50(70.4)$ & 0.005 \\
\hline Number of facilities sought before diagnosis & $3(2-4)$ & $3(1-3)$ & 0.252 \\
\hline Smear positive sputum & $53(84.1)$ & $49(69.0)$ & 0.045 \\
\hline Previous TB & $12(19.0)$ & $23(32.4)$ & 0.114 \\
\hline Correctly reported air as the main mode of transmission of TB & $37(58.7)$ & $37(52.1)$ & 0.489 \\
\hline Perceived TB as being curable & $59(93.7)$ & $69(97.2)$ & 0.570 \\
\hline Afraid of how other people will react when they know you have TB & $22(34.9)$ & $30(42.3)$ & 0.478 \\
\hline $\begin{array}{l}\text { Afraid that your friends and/or family members to move away from you if they know you } \\
\text { have TB }\end{array}$ & $17(27.0)$ & $14(19.7)$ & 0.412 \\
\hline Feel alone after discovering that you have TB & $10(15.9)$ & $17(23.9)$ & 0.285 \\
\hline Concerned to keep away from others to avoid spreading TB & $45(71.4)$ & $47(66.2)$ & 0.578 \\
\hline $\begin{array}{l}\text { Afraid or ashamed to appear in the TB health center because other people can see that } \\
\text { you are going there because you have TB }\end{array}$ & $5(7.9)$ & $6(8.5)$ & 0.999 \\
\hline Feels guilty for your family to have to be taking care of you & $13(20.6)$ & $11(15.5)$ & 0.502 \\
\hline Afraid to tell others that you have TB because they may find that you also have HIV/AIDS & $21(33.3)$ & $17(23.9)$ & 0.254 \\
\hline Fear of having HIV/AIDS & $31(49.2)$ & $40(56.3)$ & 0.488 \\
\hline $\begin{array}{l}\text { Feels guilty for having TB due to some of your habits (smoking or use of alcohol } \\
\text { beverages or other drug use) }\end{array}$ & $22(34.9)$ & $32(45.1)$ & 0.290 \\
\hline
\end{tabular}

IQR: interquartile range; SD: standard deviation.

Note: Continuous variables (age) are presented as mean $\pm \mathrm{SD}$; other data are presented as $\mathrm{n} / \mathrm{N}(\%)$ : number of cases with characteristic/total number of cases (percentage in the group), or median (interquartile range).

* 1 standard minimum wage corresponds to approximately US\$311. 
Multivariate analysis of factors associated with patient delay.

\begin{tabular}{lccc}
\hline Variables & p-value & OR & 95\%Cl \\
\hline Sought treatment because of first symptom & 0.009 & 0.203 & $0.062-0.666$ \\
Weight loss & 0.031 & 0.314 & $0.109-0.900$ \\
Constant & 0.001 & 10.745 & - \\
\hline
\end{tabular}

95\% $\mathrm{Cl}$ : 95\% confidence interval; OR: odds ratio.

\section{Discussion}

In this study, we found a median health care seeking time of 20 days. The protective factors for patient delay in multivariate analysis were weight loss, and have sought treatment because of the first symptom. We also demonstrated that approximately $50 \%$ of patients incorrectly reported the mode of transmission of TB. In addition, the local of first attendance was an emergency room of public hospitals in almost $40 \%$ of patients.

Identifying the sources of delay is a critical issue for an effective TB control. Patient delay may explain why many patients present with advanced disease and why a relatively high percentage of TB patients die. Furthermore, patient delays lead to increased spread of TB within the community $14,15,16$. There is no agreed definition of what constitutes an "acceptable" delay, and it probably depends on the local health services and the local epidemiological situation, with a shorter delay to be expected when incidence is high 17 . Care seeking or patient delay is widely variable in literature, ranging from 4.9 to 162 days 18 . In our study, patient delay was similar to that found by other authors in India 19,20, Japan 21, Hong Kong 22, and Spain 23.

Persons with suspected TB symptoms but who do not seek health care should be identified, and reasons for not seeking treatment need to be investigated. Having sought help after the appearance of the first symptom was a protective factor for patient delay in our study. The main reasons for delay among those who presented late to the health system involve financial, psychosocial and cultural characteristics of patients 24,25 .

We identified among those who did not seek treatment soon after the onset of the first symptom, that the main justifications were because they thought the symptom was normal, they thought would improve without treatment, and that they could not miss work to sought treatment. Similar reasons were described in another study: patients "thought symptoms would go away" and "symptoms not considered serious" 13 . It has also been reported that patients awaiting symptoms resolution without specific treatment and can assign them to viral infections 26,27,28,29,30.

Our results showed that weight loss was a protective factor for patient delay. In a recent study 31 , authors demonstrated that the presence of non-specific symptom of cough was a risk factor associated with longer delays, but if other pulmonary symptoms like loss of weight, for example, were considered together these delays could be shorten. Another previous study revealed that persistent cough not accompanied by symptoms such as weight loss and weakness could delay patients' first initiative to seek help ${ }^{32}$. It is possible that patients' knowledge that weight loss is one of the TB symptoms raised awareness of TB among them. However, the patients in our study demonstrate a lack of knowledge about TB, once almost one half did not know how the disease was transmitted. Misconceptions about TB transmission have been reported in other studies 33 , and it is related to delays in diagnosis and treatment non-adherence $33,34,35,36$. We could not show an association between patient delay and lack of knowledge about TB, but is important to develop strategies to improve patient education about their illness in the TB services, since it can have implications in treatment adherence. In the same way, it is important to train health professionals in identifying these patients. One study 37 conducted in Vitória, Espírito Santo State, Brazil, found that the majority of respiratory symptomatic patients $(71 \%)$ had not sought health care facility because of cough, the symptom most commonly associated with TB.

The median number of visits to health care facilities before the diagnosis was 3 , and the number of sputum smears requested in those facilities was very low (less than $40 \%$ ). Loureiro et al. 38 also demonstrated that sputum smears were requested in $42.1 \%$ of patients who sought care in primary care level. This finding could be 
related to lack of awareness of TB among health care workers 39. Another concerning finding of the present study was that the local of first attendance was an emergency room of public hospitals in almost $40 \%$ of patients. In addition, almost $30 \%$ were diagnosed and started treatment at hospitals, and did not seek treatment at health centers. The reasons for not seeking treatment in health centers were mainly poor access to medical care in such places, and lack of credibility in the treatment that can be offered there. In addition, lack of resoluteness of patient's symptoms in the primary care level is an issue to be considered. Another fact to be considered is the greater flexibility of office hours in hospitals as compared with health centers 40 . One study recently reported that most patients treated for TB in a primary health clinic in a high TB incidence city in Southeast Brazil, initially sought medical attention at an emergency room rather than the primary health care clinic, as recommended by the public health system in Brazil 41. In another study conducted in Vitoria, Brazil, $30.7 \%$ of patients initially seek treatment at an emergency room 38 . Emergency room is one of the main entrances for public health care system in Brazil, where a significant number of individuals with respiratory symptoms like cough go in order to get the first aid. Considering that emergency room is a site with a high potential for propagation of $\mathrm{TB}$, efforts should be made for early diagnosis and treatment. Furthermore, the reasons for patients seeking emergencies instead of health centers should be better investigated.

Some considerations should be taken into account when interpreting the results of this study. First, patient delays were determined retrospectively then they could have been limited by recall bias. Nevertheless, our findings indicate that there is a significant time elapsed before patients sought medical care. Second, we evaluated only patient delay, and not health care system delay, that could have a role in delay. Although delayed initial health seeking covers only a part of the total delay, it can impact on transmission. A study conducted in Foz do Iguaçu, Paraná State, Brazil showed that the time between first consultation and diagnosis was not the main problem in total time delayed, and patient delay was more important 42 . Additionally, the difficulty of establishing the boundaries between the patient delay and the health system delay was previously discussed, since previous experiences may influence patient's decision to seek the service again or delay the search for care ${ }^{42}$. Also, we chose a cutoff of 20 days (median health care seeking time) that is near the time reported in the media for seeking care (cough $\geq 2$ weeks); if we had chosen another cutoff, we might have found other associations. However, a similar cutoff was already used in a study in Brazil 43. In addition, the use of a previously validated questionnaire 44 would facilitate comparison with data from other studies. Nevertheless, the use of a specific questionnaire was useful for characterizing these patients, identifying regional differences in health assistance and factors associated with delayed diagnosis in this population. Eventually this knowledge will be helpful to adequate planning of future actions in the area studied. Finally, we did not evaluate the impact that patient delay may have on mortality. In spite of these concerns, we recruited patients from two TB services, and we expect the results may thus be applied to other similar settings.

In conclusion, we demonstrated that the median health care seeking time in two TB services in a region with a high prevalence of TB was 20 days, and the factors associated with patient delay in multivariate analysis were weight loss, and have sought treatment because of the first symptom. Also, patients studied showed a lack of knowledge of TB, and a high percentage of them first sought attendance in emergency rooms of public hospitals. Future studies on reasons for not seeking care in health centers or TB services may be warranted in this setting. In addition, our results showed that there is a need for public health interventions, focusing on TB education programs, including awareness of early symptoms of disease. 


\section{Resumen}

Los retrasos en el diagnóstico de la tuberculosis son los principales factores que impiden el control de la tuberculosis. Entre los objetivos de este estudio se encuentra la descripción de la trayectoria de los pacientes con tuberculosis, evaluando el retraso en el diagnóstico del paciente y el número de establecimientos de salud visitados antes de iniciar el tratamiento para la tuberculosis. Se realizó un estudio transversal con pacientes $\geq 18$ años de edad y con diagnóstico de tuberculosis pulmonar que respondieron a un cuestionario. La edad media de los pacientes fue de 40,4 $\pm 16,1$. Se encontró un media de 20 días en el retraso del diagnóstico a los pacientes. También se halló que un 44,8 \% informó incorrectamente del modo de transmisión de la tuberculosis. Por otra parte, el primer punto de asistencia para un $37,3 \%$ de los pacientes fue el servicio de urgencias en un hospital público. Se halló un promedio de 20 días en el retraso del diagnóstico de la tuberculosis a los pacientes, los factores protectores asociados con el retraso en el análisis multivariado fueron la pérdida de peso y conseguir el tratamiento debido cuando se presenta el primer síntoma.

Tuberculosis; Diagnóstico Tardío; Tiempo de Tratamiento

\section{Contributors}

C. P. B. Almeida designed the study, collected data, and help to draft the manuscript. E. K. Skupien collected and analyzed data, and help to draft the manuscript D. R. Silva designed the study, analyzed data, and wrote the paper.

\section{Acknowledgments}

We would like to acknowledge the support from the International Clinical Operational Health Services Research Training Award (ICOHRTA/Fogarty International Center/National Institutes for Health -NIH) and Johns Hopkins University (Johns Hopkins Bloomberg School of Public Health).

\section{Conflicts of interest}

The authors have no conflicts of interest to disclose.

\section{References}

1. World Health Organization. Tuberculosis fact sheet. http://www.who.int (accessed on 15/May/ 2013).

2. Odusanya OO, Babafemi JO. Patterns of delays amongst pulmonary tuberculosis patients in Lagos, Nigeria. BMC Public Health 2004; 4:18.

3. Lawn SD, Afful B, Acheampong JW. Pulmonary tuberculosis: diagnostic delay in Ghanaian adults. Int J Tuberc Lung Dis 1998; 2:635-40.

4. Ward HA, Marciniuk DD, Pahwa P, Hoeppner VH. Extent of pulmonary tuberculosis in patients diagnosed by active compared to passive case finding. Int J Tuberc Lung Dis 2004; 8:593-7.

5. Yimer S, Bjune G, Alene G. Diagnostic and treatment delay among pulmonary tuberculosis patients in Ethiopia: a cross sectional study. BMC Infect Dis 2005; 5:112.
6. Sherman LF, Fujiwara PI, Cook SV, Bazerman LB, Frieden TR. Patient and health care system delays in the diagnosis and treatment of tuberculosis. Int J Tuberc Lung Dis 1999; 3:1088-95.

7. Ngamvithayapong J, Yanai H, Winkvist A, Diwan V. Health seeking behaviour and diagnosis for pulmonary tuberculosis in an HIV-epidemic mountainous area of Thailand. Int J Tuberc Lung Dis 2001; 5:1013-20.

8. dos Santos MA, Albuquerque MF, Ximenes RA, Lucena-Silva NL, Braga C, Campelo AR, et al. Risk factors for treatment delay in pulmonary tuberculosis in Recife, Brazil. BMC Public Health 2005; 5:25.

9. Storla DG, Yimer S, Bjune GA. A systematic review of delay in the diagnosis and treatment of tuberculosis. BMC Public Health 2008; 8:15. 
10. Prefeitura Municipal de Porto Alegre. Os mapas das taxas de incidência da tuberculose e AIDS por Gerências Distritais de Saúde de Porto Alegre. Boletim Epidemiológico 2008; (36). http:// www.portoalegre.rs.gov.br/sms (accessed on 20/ May/2013).

11. Prefeitura Municipal de Porto Alegre. O impacto do sistema de mortalidade na vigilância epidemiológica da tuberculose em Porto Alegre. Boletim Epidemiológico 2012; (48). http://www.portoalegre.rs.gov.br/sms (accessed on 20/May/2013).

12. Conde MB, Melo FA, Marques AM, Cardoso NC, Pinheiro VG, Dalcin PT, et al. III Brazilian Thoracic Association guidelines on tuberculosis. J Bras Pneumol 2009; 35:1018-48.

13. van der Werf MJ, Chechulin Y, Yegorova OB, Marcinuk T, Stopolyanskiy A, Voloschuk V, et al. Health care seeking behaviour for tuberculosis symptoms in Kiev City, Ukraine. Int J Tuberc Lung Dis 2006; 10:390-5.

14. Harries AD, Hargreaves NJ, Gausi F, Kwanjana JH, Salaniponi FM. High early death rate in tuberculosis patients in Malawi. Int J Tuberc Lung Dis 2001; 5:1000-5.

15. Harries AD, Nyirenda TE, Godfrey-Faussett P, Salaniponi FM. Defining and assessing the maximum number of visits patients should make to a health facility to obtain a diagnosis of pulmonary tuberculosis. Int J Tuberc Lung Dis 2003; 7:953-8.

16. Sonnenberg P, Glynn JR, Fielding K, Murray J, Godfrey-Faussett P, Shearer S. HIV and pulmonary tuberculosis: the impact goes beyond those infected with HIV. AIDS 2004; 18:657-62.

17. Ward J, Siskind V, Konstantinos A. Patient and health care system delays in Queensland tuberculosis patients, 1985-1998. Int J Tuberc Lung Dis 2001; 5:1021-7.

18. Sreeramareddy CT, Panduru KV, Menten J, Van den Ende J. Time delays in diagnosis of pulmonary tuberculosis: a systematic review of literature. BMC Infect Dis 2009; 9:91.

19. Rajeswari R, Chandrasekaran V, Suhadev M, Sivasubramaniam S, Sudha G, Renu G. Factors associated with patient and health system delays in the diagnosis of tuberculosis in South India. Int J Tuberc Lung Dis 2002; 6:789-95.

20. Tobgay KJ, Sarma PS, Thankappan KR. Predictors of treatment delays for tuberculosis in Sikkim. Natl Med J India 2006; 19:60-3.

21. Sasaki Y, Yamagishi F, Yagi T, Yamatani H, Kuroda F, Shoda H. A study of patient's and doctor's delay in patients with pulmonary tuberculosis discovered by visiting doctors with symptoms in particular on doctor's delay. Kekkaku 2000; 75:527-32.

22. Leung EC, Leung CC, Tam CM. Delayed presentation and treatment of newly diagnosed pulmonary tuberculosis patients in Hong Kong. Hong Kong Med J 2007; 13:221-7.

23. Diez M, Bleda MJ, Alcaide J, Caloto T, Castells C, Cardenal JI, et al. Determinants of patient delay among tuberculosis cases in Spain. Eur J Public Health 2004; 14:151-5.
24. Khan A, Walley J, Newell J, Imdad N. Tuberculosis in Pakistan: socio-cultural constraints and opportunities in treatment. Soc Sci Med 2000; 50:247-54.

25. Needham DM, Godfrey-Faussett P, Foster SD. Barriers to tuberculosis control in urban Zambia: the economic impact and burden on patients prior to diagnosis. Int J Tuberc Lung Dis 1998; 2:811-7.

26. Caceres-Manrique FM, Orozco-Vargas LC. Demora en el diagnóstico de tuberculosis pulmonar en una región de Colombia. Rev Salud Pública 2008; 10:94-104.

27. Gershon AS, Wobeser W, Tu JV. Delayed tuberculosis treatment in urban and suburban Ontario. Can Respir J 2008; 15:244-8.

28. Karim F, Islam MA, Chowdhury AM, Johansson E, Diwan VK. Gender differences in delays in diagnosis and treatment of tuberculosis. Health Policy Plan 2007; 22:329-34.

29. Maamari F. Case-finding tuberculosis patients: diagnostic and treatment delays and their determinants. East Mediterr Health J 2008; 14:531-45.

30. Zerbini E, Chirico MC, Salvadores B, Amigot B, Estrada S, Algorry G. Delay in tuberculosis diagnosis and treatment in four provinces of Argentina. Int J Tuberc Lung Dis 2008; 12:63-8.

31. Meyssonnier V, Li X, Shen X, Wang H, Li DY, Liu $Z M$, et al. Factors associated with delayed tuberculosis diagnosis in China. Eur J Public Health 2013; 23:253-7.

32. Sagbakken M, Bjune GA, Frich JC. Experiences of being diagnosed with tuberculosis among immigrants in Norway: factors associated with diagnostic delay: a qualitative study. Scand J Public Health 2010; 38:283-90.

33. Deribew A, Abebe G, Apers L, Jira C, Tesfaye M, Shifa J, et al. Prejudice and misconceptions about tuberculosis and HIV in rural and urban communities in Ethiopia: a challenge for the TB/HIV control program. BMC Public Health 2010; 10:400.

34. Courtwright A, Turner AN. Tuberculosis and stigmatization: pathways and interventions. Public Health Rep 2010; 125 Suppl 4:34-42.

35. Mushtaq MU, Majrooh MA, Ahmad W, Rizwan M, Luqman MQ, Aslam MJ, et al. Knowledge, attitudes and practices regarding tuberculosis in two districts of Punjab, Pakistan. Int J Tuberc Lung Dis 2010; 14:303-10.

36. Somma D, Thomas BE, Karim F, Kemp J, Arias N, Auer C, et al. Gender and socio-cultural determinants of TB-related stigma in Bangladesh, India, Malawi and Colombia. Int J Tuberc Lung Dis 2008; 12:856-66.

37. Moreira CM, Zandonade E, Lacerda T, Maciel EL. Sintomáticos respiratórios nas unidades de atenção primária no Município de Vitória, Espírito Santo, Brasil. Cad Saúde Pública 2010; 26:1619-26.

38. Loureiro RB, Villa TC, Ruffino-Netto A, Peres RL, Braga JU, Zandonade E, et al. Access to the diagnosis of tuberculosis in health services in the municipality of Vitoria, state of Espirito Santo, Brazil. Ciênc Saúde Coletiva 2014; 19:1233-44. 
39. Campos CEA, Fonseca ACF, Pessini ML. Análise dos percursos assistenciais de pacientes com tuberculose por equipes de saúde em três capitais brasileiras. Que lições os profissionais podem tirar? Cad Saúde Colet (Rio J.) 2012; 20:188-94.

40. de Oliveira MF, Arcencio RA, Ruffino-Netto A, Scatena LM, Palha PF, Villa TC. The front door of the Ribeirao Preto health system for diagnosing tuberculosis. Rev Esc Enferm USP 2011; 45:898-904.

41. Maior ML, Guerra RL, Cailleaux-Cezar M, Golub JE, Conde MB. Time from symptom onset to the initiation of treatment of pulmonary tuberculosis in a city with a high incidence of the disease. J Bras Pneumol 2012; 38:202-9.

42. Silva-Sobrinho RA, Andrade RL, Ponce MA, Wysocki AD, Brunello ME, Scatena LM, et al. Delays in the diagnosis of tuberculosis in a town at the triple border of Brazil, Paraguay, and Argentina. Rev Panam Salud Pública 2012; 31:461-8.
43. Machado AC, Steffen RE, Oxlade O, Menzies D, Kritski A, Trajman A. Factors associated with delayed diagnosis of pulmonary tuberculosis in the state of Rio de Janeiro, Brazil. J Bras Pneumol 2011; 37:512-20.

44. Villa TC, Ruffino-Netto A. Performance assessment questionnaire regarding TB control for use in primary health care clinics in Brazil. J Bras Pneumol 2009; 35:610-2.

Submitted on 18/Nov/2013

Final version resubmitted on 17/Jul/2014

Approved on 04/Sep/2014 